\title{
Effects of Citrobacter freundii ATP Production and Oxygen Intake Two Different Plasmids Carrying the Vitreoscilla Hemoglobin Gene (vgb)
}

\author{
Hüseyin Kahraman*1, Aslı Giray Kurt ${ }^{1}$ \\ ${ }^{1}$ Inönü Üniversitesi, Fen Edebiyat Fakültesi, Biyoloji Bölümü, 44280, Malatya. \\ e-posta: huseyin.kahraman@inonu.edu.tr
}

Geliş Tarihi: 28.09.2016 ; Kabul Tarihi: 29.03.2017

Keywords
Citrobacter freundii,
Vitreoscilla hemoglobin gene
$(v g b)$,
ATP production,
Oxygen uptake

\section{Vitreoscilla Hemoglobin Geni (vgb) Taşıyan iki Farklı Plazmidin Citrobacter freundii'nin ATP Üretimi ve Oksijen Alınımına Etkileri}

Anahtar Kelimeler

Citrobacter freundii, Vitreoscilla hemoglobin geni ( $v g b)$,

ATP üretimi, Oksijen alınımı

\begin{abstract}
Özet:
Bu çalışmada, ATP üretimi, oksijen alımı ve hücre kütlesi üretimi üzerinde yeniden birleştirici oksijen alımı sisteminin kullanılması araştırılmıştır. Citrobacter freundii ve onun vgb rekombinantları kullanılmıştır. Citrobacter freundii de geniş bir konakçı aralığında çalışan plazmitler Cf [PMK'yi 79] ve Cf [pUC8: 15] kullanılmıştır. En İyi ATP üretimi Cf [PMK 79] $(0,17 \mathrm{mg} / \mathrm{g})$. Cf [pMK79] oksijen alımının seviyesi, Cf[pUC8:15] daha yüksektir. Oysa Cf [pMK79]'un $\mathrm{OD}_{600}$ değerleri 48 saat sonunda düşmektedir.
\end{abstract}

(C) Afyon Kocatepe Üniversitesi

\section{Introduction}

Bioenergetics plays a very important role in understanding the behavior of microorganisms (Zeng et al., 1990). Energy metabolism is an important metabolic pathway which maintains biochemical and physiological activities for the living organisms (Liu et al., 2006). ATP is a universal energy carrier in biological systems and contributes to biochemical reactions. Measurement of cellular ATP levels in living cells is crucial for assessing their metabolic state (Ivanova et al., 2006). All living things use adenosine triphosphate ATP for energy. ATP is used as primary energy sources currency by all organisms. There are significant amounts of knowledge about the ecological and physiological significance of ATP and oxygen consumption (Velten et al., 2007). Plasmid DNA has been used for a long time microbial physiological and biochemical studies (O'Mahony et al., 2005). Citrobacter freundii, Gram-negative, nonperforming rods, non-sporeforming rods belonging to the Enterobacteriaceae and found in soil, water, sewage, animal and human (Borenshtein and Schauer 2006; LozanoLeon et al., 2011; Wang et al., 2000). Hemoglobins are a specific group of oxygen-binding proteins 
that can be found in many organisms. The hemoglobin (VHb), from Vitreoscilla (a Gramnegative, aerobic bacterium) is among the bestcharacterized prokaryotic ones. The in vivo role of $\mathrm{VHb}$ is suggested oxygen trapping/transfer, allowing this bacterium to survive and grow in microaerobic environments. It is known that recombinant (plasmid carrying) bacterial cells have a growth disadvantage, require more oxygen (due to perturbations in cellular metabolism) then grow disproportionately poorly under oxygen-limited conditions compared with plasmid-free cells (Erenler et al., 2004). The major function of VHb was the binding of oxygen and increasing ATP production under hypoxic conditions (Stark et al., 2011). We repot here expression of $\mathrm{VHb}$ and its effect on ATP production, oxygen uptake and cell mass of pMK79 and pUC8:15 from Citrobacter freundii. According to our survey could not be reached on this issue sufficient resource.

\section{Material and Method}

\subsection{Bacterial strain}

Bacterial strain Citrobacter freundii (NRRL B-2643) $v g b$ bearing the different plasmid pMK79 (Cf[MK79]) (Figure 1) and pUC8:15 (Cf[pUC8:15]) (Figure 2) was used in this study.

\subsection{Growth conditions}

C. freundii and their strains were grown LuriaBertani medium (LB). LB broth medium (g/ l); peptone (10), $\mathrm{NaCl}$ (10), and yeast extract (5). Cells were maintained on LB agar plates at $4{ }^{\circ} \mathrm{C}$ with transfers at monthly intervals.

ATP production, oxygen intake, $\mathrm{pH}$ and $\mathrm{OD}_{600}$ compared to the amount of by cells in LB medium. The final $\mathrm{pH}$ values of this media were adjusted to acid 7.0. A $1 / 100$ inoculum of overnight our cultures grown on $50 \mathrm{ml}$ LB in $150 \mathrm{ml}$ Erlenmeyer flasks and inoculated into $50 \mathrm{ml}$ of the same medium in $150 \mathrm{ml}$ volume flasks. Then flasks incubated for 96 hour and at $37^{\circ} \mathrm{C}$ in a $200 \mathrm{rpm}$.

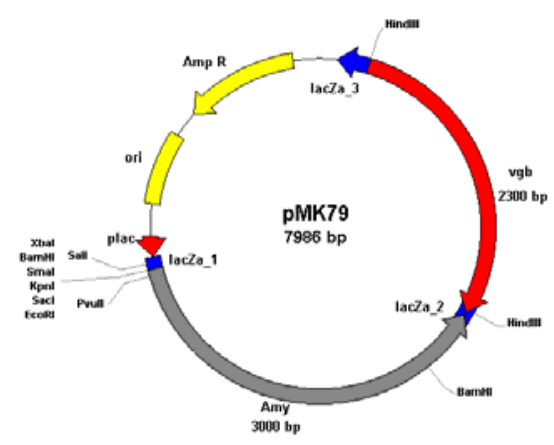

Figure 1. Map of of Cf[pMK79]

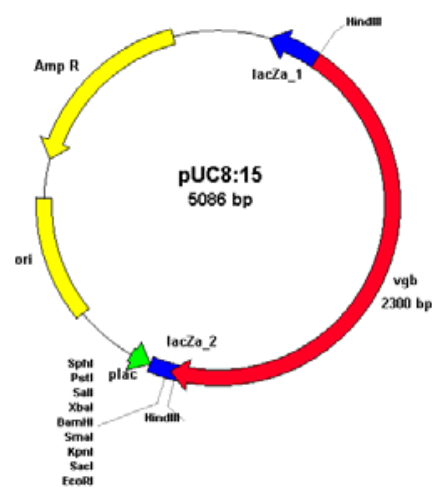

Figure 2. Map of of $\mathrm{Cf}[\mathrm{pUC} 8: 15]$

\subsection{Cell densities}

The cell densities were measured at $O D_{600}$ every 24 h using UV/Vis Beckman 640 spectrophotometer.

\subsection{Mobile phases}

The mobile phase composition is given in table 1 . Air bubbles in the two solutions were driven away using an ultrasonic instrument. Final solution stored at $-30^{\circ} \mathrm{C}$ for analysis.

Adenosine phosphates were extracted from the powder with $10 \mathrm{ml}$ of $0.6 \mathrm{M}$ perchloric acid in the ice bath for $1 \mathrm{~min}$. The extraction mixture was centrifuged for $10 \mathrm{~min}$ at $6000 \times \mathrm{g}$ (Beckman J202) and $4{ }^{\circ} \mathrm{C}$, and $6 \mathrm{ml}$ of the supernatant was taken and quickly neutralized to $\mathrm{pH}$ 6.5-6.8 with $1 \mathrm{M} \mathrm{KOH}$ solution. The neutralized supernatant was then 
allowed to stand for $30 \mathrm{~min}$ in an ice bath to precipitate most of the potassium perchlorate and removed by paper filtration. The filtrate solution was filtered again through a $0.45 \mathrm{~mm}$ filter. The final filtrate solution was made up to $8 \mathrm{ml}$ and then stored at $-30{ }^{\circ} \mathrm{C}$ prior to the analysis.

Table 1. HPLC Method Parameters

\begin{tabular}{ll}
\hline Parameter & \\
\hline Colon & Agilent 1100 Series; \\
& ACE 5 C18 (4,6 x 250 \\
& mm) \\
Dedector & DAD \\
Mobile phase (ml) & A: The phosphate \\
& buffer $\quad\left(\mathrm{KH}_{2} \mathrm{PO}_{4}-\right.$ \\
& $\left.\mathrm{K}_{2} \mathrm{HPO}_{4}\right)$ pH: $7.0 ;$ \\
& B: acetonitrile
\end{tabular}

Mobile phase

velocity $(\mathrm{ml} / \mathrm{min}) \quad 1.2$

The column

Temperature $\quad 20^{\circ} \mathrm{C}$

The wavelength (nm) 254

Criteria for the

calculation Peak area

\subsection{HPLC analysis of ATP}

Cultures of wild type and recombinant bacterial strains were incubated during 96 hours. The cultures were centrifuged at $6000 \mathrm{rpm}$ at $4{ }^{\circ} \mathrm{C}$ for 10 minutes. Weight of the pellet after centrifugation was adjusted to $0.5 \mathrm{~g}$ and $2.5 \mathrm{ml}$ of perchloric acid was added to the pellet. Examples were kept for $1 \mathrm{~min}$ on ice. Extraction of the mixture was centrifuged for $10 \mathrm{~min}$ at $6000 \mathrm{rpm}$ at $4{ }^{\circ} \mathrm{C}$. The supernatant was taken and immediately neutralized to $\mathrm{pH}$ 6.5-6.8 with $1 \mathrm{M} \mathrm{KOH}$ solution. The supernatant was then allowed to stand for 30 $\min$ in an ice bath to precipitate most of the potassium perchlorate. The supernatant was filtered through a $0.45-\mathrm{mm}$ filter and $20 \mu \mathrm{l}$ of supernatant was injected for HPLC analysis after supernatant was filtered and then the measurements were made at $254 \mathrm{~nm}$. Determination of the amount of ATP produced by the cells the Agilent 1100 Series, C18 (4.6 x 250 $\mathrm{mm}$ ) was measured by HPLC. The analysis in Table
1 was performed according to the parameters of the device. In order to analysis of ATP to $1000 \mathrm{mg} /$ I (100 ppm) of the stock solutions was prepared. Calibration standards for $0.2-4 \mathrm{mg} / \mathrm{I}(0.2,0.5,1$, $2,4 \mathrm{ppm}$ ) in the range of $100 \mathrm{mg} / \mathrm{I}(100 \mathrm{ppm})$ out of the stock solution was prepared by dilutions. Calibration curves were obtained using pure ATP standard. The correlation coefficients for calibration curves were generally at the level of $\geq$ 0.99 .

The amount of ATP in the cells was determined by HPLC method parameters given in the Table 1.

\subsection{Oxygen uptake}

In order to determine the oxygen content of the oxygen uptake of cells known as a buffer $(0.1 \mathrm{M}$ potassium phosphate, $\mathrm{pH}$ 7.6) was prepared. This buffer saturated with oxygen mixed with magnetic stirrer at $400 \mathrm{rpm}$ overnight. Calculation of consumption of oxygen by bacteria, with $4 \mathrm{ml}$ of this buffer was calculated based on the check tube. In this tube, the oxygen level was regarded as $100 \%$. Decrease in the purchasing power of oxygen to the bacteria that cause the bacteria are expressed as $10 \%$ of oxygen. Rates of oxygen uptake of the cells, was determined every 24 hours. Buffer saturated with oxygen, the oxygen concentration at $25 \stackrel{\circ}{\circ} \mathrm{C}$ in the tube $250 \mu \mathrm{M}, 32 \stackrel{\circ}{\circ}$, $233 \mu \mathrm{M}$ at $37 \stackrel{\circ}{ } \mathrm{C}$ and $218 \mu \mathrm{M}$, respectively. Bacteria use oxygen intake rates;

$\mathrm{R}=\mathrm{N} \mu \mathrm{mol} / \mathrm{I} \times(4 / 1000) \mathrm{L} \times \mathrm{D} / \mathrm{VT}$

$R=$ the consumed oxygen

$\mathrm{N}=$ the concentration of oxygen contained in the buffer

$\mathrm{D}=\%$ reduced rate of oxygen

$\mathrm{V}=$ Live cell number

$T=$ time taken for oxygen consumption rate (for $D$ ) 


\section{Results}

Plasmids with different characteristics, physiological effects of $v g b$ gene transferred to our laboratory for the first time tried the same bacterium. The map of pMK79 and pUC8:15 are shown in Figure 1 and 2. pMK79 is an additional 3 $\mathrm{kb}$ amylase gene. However, pUC8:15 have more restriction enzyme cutting area. Both pMK79 and pUC8:15 ATP production increased by up to 48th hour after that time is decreased production of ATP. Best ATP production by pMK79 $(0.17 \mathrm{mg} / \mathrm{g})$. After 72 hours decreased ATP production pMK79; pUC8: 15 in remains constant (Figure 3).

pMK79 strain the level of intracellular ATP was higher than pUC8:15 at all time points during the growth. pMK79 had average 1.9-fold higher than the pUC8:15. There was a substantial (3-6 -fold) decrease in ATP production of pMK79 and pUC8:15 upon entering stationary phase. There was a trend for ATP levels pMK79 to be higher than those of pUC8:15 all during time.

The oxygen uptake rates of pMK79 and pUC8:15 grown in LB were determined. The oxygen uptakes of cultures were measured both per cell and per unit cell mass. Oxygen uptake, depending on the aging time and culture, pMK79 and pUC8:15 decreasing. A significant decrease in oxygen uptake is observed with time. We think the reason for this is related to the aging of the culture medium closed. However, the pUC8:15, though mild, was on the rise at the end of 72 hours. The highest oxygen uptake 24 hours, while the lowest value it has been 96 hours (pMK79) (Figure 4).

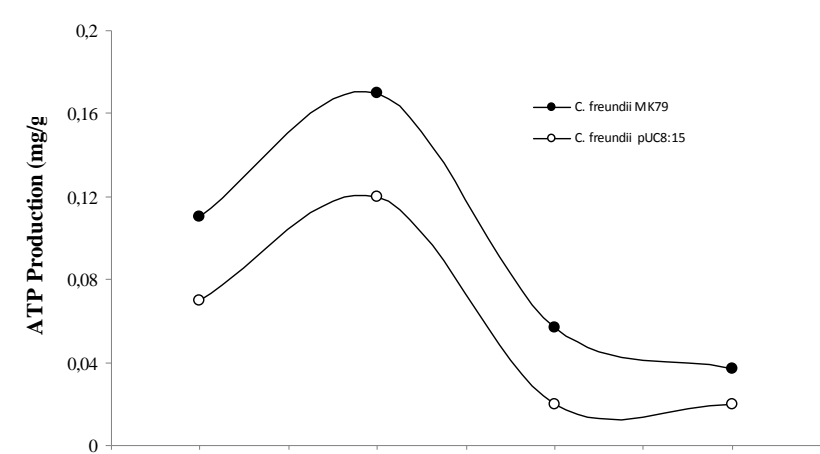

Figure 3. $\mathrm{A}^{24} \mathrm{P}$ production of $C$. freundii $\mathrm{pMK} 79^{76}$ and pUC8:15.

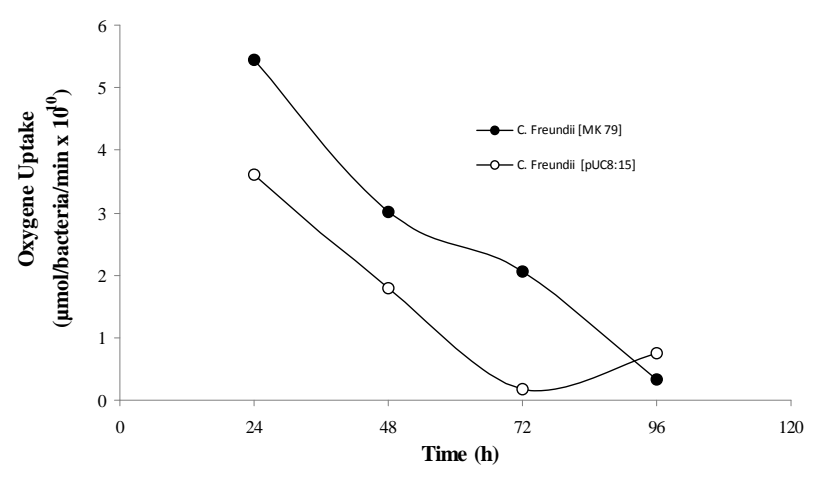

Figure 4. Oxygen uptake of C. freundii pMK79 and pUC8:15.

$\mathrm{OD}_{600}$ values reached the highest values up to 48 hours $\left(\mathrm{OD}_{600}\right.$ pMK79 5.23 and pUC 8:15 4.56). Began to dream at the end of 48 hours, and 72 hours and reached the lowest value $\left(O D_{600} 2.22\right)$ in the MK79. However, a rapid increase again observed. $\mathrm{OD}_{600}$ was less variation in pUC 8:15 (Figure 5). For this reason is selective pressure (nutrient and oxygen depletion). However, those who are resistant cause an increase in unilateralism. MK79, which carries the most amylase gene that is most affected by this activity.

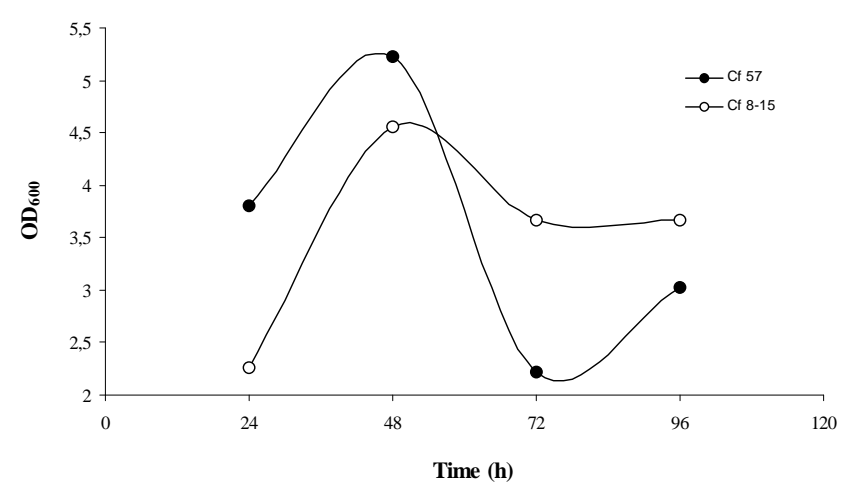

Figure 5. Growth cell mass of $C$. freundii pMK79 and pUC8:15.

Average $\mathrm{pH} 9.2$ of the culture medium at the end of the study was a steady increase. There is no significant difference between the two cultures $\mathrm{pH}$ maintenance (Figure 6). Two strains showed similar $\mathrm{pH}$ values during the same cultivation periods. No significant difference was observed between the levels of pH. pMK79 strain the level of oxygen uptake was higher than pUC8:15. Whereas 
pMK79 the $O D_{600}$ values have been falling at the end of 48 hours (Figure. 4 and 5).

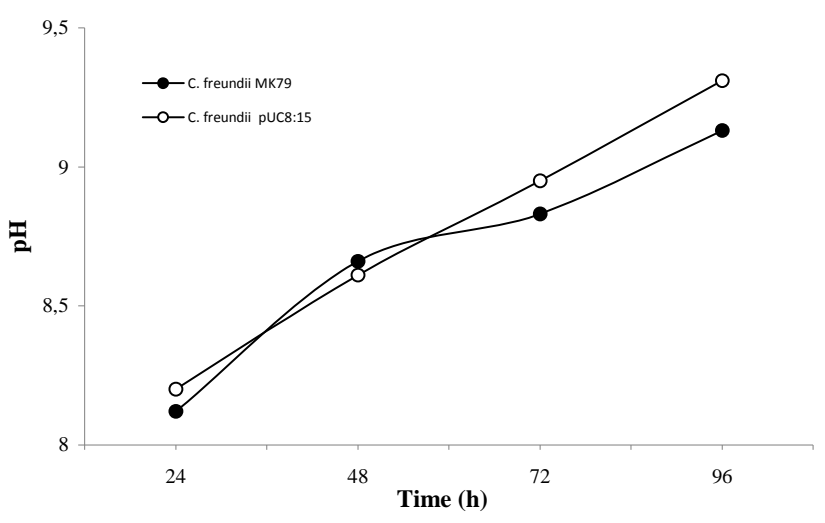

Figure 6. $\mathrm{pH}$ values of $C$. freundii pMK79 and pUC8:15.

\section{Discussion}

In this study, two different characteristics $v g b$ transferred plasmid, production of ATP, the oxygen effect of cell density and $\mathrm{pH}$ were studied. VHb may be the result of enhanced respiration, and this ATP production, the absence of oxygen.

These strains there was a decrease in respiration rate upon going from log to stationary phases. At the end of 72 hours, depending on the decrease in the environment $\mathrm{VHb}$ increased production of oxygen $(10 \%$ under atmospheric maximum working promoter), depending on the cell density and an increase in the production of ATP observed. In normal circumstances would have observed a steady decline in these values.

The aerobic bacterial oxygen uptake rate and ATP production is an indicator of microbial growth and metabolism and metabolite production in a diverse field of applications. Also, the oxygen uptake rate of both $E$. coli and $P$. aeruginosa was determined to improve with presence of $\mathrm{VHb}$ (Erenler et al., 2004). The oxygen uptake rate of cells was increased in the presence of $\mathrm{VHb}$ (Geckil et al.,2001). Geckil et al. 2001 reported that the oxygen uptake rates of both $E$. coli and $P$. aeruginosa, carrying plasmid (in $v g b$ ) were higher than the wild strains. The oxygen uptake rates changes (per cell basis) of pUC8:15 and pMK79 were similar. However, the oxygen uptake rate of
pMK79 was more than 11 times higher than that of the other strains at the $72 \mathrm{~h}$ time point here is in different the results of Geckil et al. (2001). The difference in oxygen uptake decreased at longer time and the respiration rate decreased for both strains. After that, the hope will be an example for similar studies.

$\mathrm{VHb}$ enhancing aerobic respiration and this in cellular ATP level were increased (Stark et al., 2012). Although having the same molecular size of hemoglobin, pMK79 has more base pairs than pUC 8:15. pMK79; ATP production, oxygen uptake and cell mass values more than $\mathrm{pUC8:15}$.

When looking at $\mathrm{OD}_{600}$ values $\mathrm{pMK} 79$ seen a decline rapidly after 48 hour. In oxygen uptake rate and the production of ATP is shown the same decrease. Working environment is the biggest factor is a closed system. Despite this, pMK79, oxygen uptake and ATP have advantages in manufacturing. Needed oxygen uptake and ATP are more appropriate pMK79.

As a result, physiological changes were observed between the two plasmids. Plasmid profiles of gene expression in looking at these conclusions are understood to be effective.

The substantially higher physiological parameters pMK79 than pUC8:15 strains during the same cultivation periods might be due to the positive effect of $\mathrm{VHb}$ on amylase gene through the physiology of the cell.

\section{Acknowledgements}

The authors would like to thank the Research Fund Unit of Inonu University for financial support (APYB 2010/18).

\section{References}

Zeng, A., Ross, A. and Deckwer, W., 1990. A method to estimate the efficiency of oxidative phosphorylation and biomass yield from ATP of a facultative anaerobe in continuous culture. Biotechnology and Bioengineering, 36, 965969. 
Liu, H., Jiang, Y., Luo, Y. and Jiang, W., 2006. A simple and rapid determination of ATP, ADP and AMP concentrations in pericarp tissue of litchi fruit by high performance liquid chromatography. Food Technology and Biotechnology, 44(4), 531- 534.

Ivanova, E.P., Alexeeva, Y.V., Pham, D.K., Wright, J.P. and Nicolau, D.V., 2006. ATP level variations in heterotrophic bacteria during attachment on hydrophilic and hydrophobic surfaces. International Journal of Microbiology, 9, 37-46.

Velten, S., Hammes, F., Boller, M. and Egli, T., 2007. Rapid and direct estimation of active biomass on granular activated carbon through adenosine tri-phosphate (ATP) determination. Water Research, 41, 1973-1983.

O'Mahony, K., Freitag, R., Hilbrig, F., Müller, P. and Schumacher, I., 2005. Proposal for a better integration of bacterial lysis into the production of plasmid DNA at large scale. Journal of Biotechnology, 119, 118-132.

Wang, J., Chang, S., Chen, Y. and Luh, K., 2000. Comparison of antimicrobial susceptibility of Citrobacter freundii isolates in two different time periods. Journal of Microbiology, Immunology and Infection, 33, 258-262.

Borenshtein, D. and Schauer, D.B., 2006. The genus Citrobacter. Prokaryotes, 6, 90-98.

Lozano-Leon, A, Iglesias-Canle, J, Iglesias-Garcia, J, Larino-Noia, J. and Dominguez-Muñoz, E., 2011. Citrobacter freundii infection after acute necrotizing pancreatitis in a patient with a pancreatic pseudocyst: a case report. Journal of Medical Case Reports, 5, 51-54.

Erenler, S.O., Gencer, S., Geckil, H., Stark, B.C. and Webster, D.A., 2004. Cloning and Expression of the Vitreoscilla hemoglobin gene in Enterobacter aerogenes: effect on cell growth and oxygen uptake. Applied Biochemistry and Microbiology, 40(3), 241-248.

Stark, B.C., Dikshit, K.L. and Pagilla, K.R., 2011. Recent advances in understanding the structure, function, and biotechnological usefulness of the hemoglobin from the bacterium Vitreoscilla. Biotechnology Letters, 33, 1705-1714.

Geckil, H., Stark, B.C. and Webster, D.A., 2001. Genetically engineered Vitreoscilla hemoglobin gene. Journal of Biotechnology, 85, 5-66.

Stark, B.C., Dikshit, K.L. and Pagilla, K.R., 2012. The Biochemistry of Vitreoscilla hemoglobin. Computational and Structural Biotechnology Journal, 3 (4), 1-8. 